OPEN ACCESS

Edited by:

Ivan Gomez-Mestre,

Estación Biológica de Doñana

(EBD), Spain

Reviewed by:

Katja Räsänen,

Swiss Federal Institute of Aquatic Science and Technology, Switzerland

Pablo Burraco,

Uppsala University, Sweden

*Correspondence:

Edward J. Narayan

e.narayan@westernsydney.edu.au

Specialty section:

This article was submitted to Behavioral and Evolutionary Ecology,

a section of the journal

Frontiers in Ecology and Evolution

Received: 29 March 2019

Accepted: 23 October 2019

Published: 19 November 2019

Citation:

Narayan EJ, Forsburg ZR, Davis DR and Gabor CR (2019) Non-invasive

Methods for Measuring and

Monitoring Stress Physiology in

Imperiled Amphibians.

Front. Ecol. Evol. 7:431.

doi: 10.3389/fevo.2019.00431

\section{Non-invasive Methods for Measuring and Monitoring Stress Physiology in Imperiled Amphibians}

\author{
Edward J. Narayan ${ }^{1,2 *}$, Zachery R. Forsburg ${ }^{3}$, Drew R. Davis ${ }^{4}$ and Caitlin R. Gabor ${ }^{3}$ \\ ${ }^{1}$ School of Science and Health, University of Western Sydney, Penrith, NSW, Australia, ${ }^{2}$ Faculty of Science, School of \\ Agriculture and Food Sciences, The University of Queensland, St Lucia, QLD, Australia, ${ }^{3}$ Department of Biology, Texas State \\ University, San Marcos, TX, United States, ${ }^{4}$ School of Earth, Environmental, and Marine Sciences, University of Texas Rio \\ Grande Valley, South Padre Island, TX, United States
}

Global climate change is negatively impacting global biodiversity and ectothermic vertebrates, with amphibians being the most imperiled vertebrate taxa. Increased mean global atmospheric temperatures, high rates of habitat degradation, and exposure to infectious diseases, such as chytridiomycosis, have contributed to population declines and extinctions of rare and endangered amphibian species. Field-based monitoring of physiological endocrine traits can help determine the sub-lethal effects of environmental stressors and provide early alerts when populations are chronically stressed. Recent advances in amphibian stress endocrinology include the development and use of non-invasive methods to quantify the glucocorticoid, or stress biomarker, corticosterone. Non-invasive methods, such as urinary, skin and buccal swabs, and water-borne hormone monitoring methods (suited for terrestrial and aquatic dwelling species), are available to quantify baseline and short-term physiological stress responses of amphibians under field settings. In this review, we illustrate, by using two case studies of aquatic and terrestrial amphibian species, the applications of non-invasive corticosterone monitoring methods to advance the ecological knowledge and conservation of imperiled amphibian species, discuss the limitations of these methods, and provide future directions for the use of non-invasive hormone monitoring methods. We highlight the use of non-invasive field endocrinology methods to monitor the impacts of environmental stressors on the physiology of amphibians, which can be applied to advance ecological research, conservation, and management of imperiled species.

Keywords: conservation, ecology, ecophysiology, glucocorticoids, invasion, stress physiology, threatened species

\section{INTRODUCTION}

Global biodiversity is threatened by many anthropogenic changes, including climate change, habitat alteration, and invasive species (Brook et al., 2008; Sigwart et al., 2018). At the forefront of the biodiversity crisis are worldwide amphibian population declines and extinctions (McCaffery et al., 2012), including species in relatively undisturbed environments, such as small islands. Despite existing on Earth for over 300 million years (Stuart et al., 2004), at least 168 amphibian species are believed to be extinct and $43 \%$ of extant populations are in decline (Stuart et al., 2004; Wake and Vredenburg, 2008; Lips, 2018). Given the current rapid rates of extreme environmental change, 
many amphibian populations globally are unable to cope with these disturbances, resulting in widespread declines (Stuart et al., 2004).

Endocrine titers, such as glucocorticoid hormones (GCs) associated with the physiological stress response, play an important function in animal growth and development, ecology, behavior, and in maintaining homeostasis (Mills et al., 2004; Romero et al., 2009; Lindsay et al., 2016). GCs are metabolic hormones associated with a stress response (and are considered a biomarker of stress), which act collectively with a large network of neurohormones and a suite of biochemical and physiological processes that aid organisms in maintaining homeostasis (MacDougall-Shackleton et al., 2019). A stress response of elevated GC levels is indicative of a functioning hypothalamus-pituitary-interrenal (HPI) axis and as individuals become chronically stressed, GC levels may become permanently elevated (homeostatic overload) or permanently suppressed (homeostatic failure; Romero et al., 2009). Exposure to chronic stressors, such as extreme drought and invasive species can lead to decreased physiological health, population declines, and loss of genetic variation (Dantzer et al., 2014). Baseline and stress-induced corticosterone is heritable based on studies with birds (reviewed by Hau et al., 2016). By repeatedly measuring baseline levels of circulating GCs over time, and quantifying how individuals respond to acute stressors, one can infer if an organism is stressed (acute or chronic) or indeed showing physiological acclimation and the capacity to cope with stressors over the long term (Łopucki et al., 2018; Vitousek et al., 2019a). Noninvasive methods to measure GCs can advance our knowledge of species' eco-physiological responses to environmental change, provide a metric of the physiological health of a population, which may provide an early indication of population declines, and thus support conservation and proactive management programs.

The primary aim of this mini-review is to explore the applications, benefits, and limitations of non-invasive methods for measuring corticosterone (the main GC in amphibians: Idler, 1972; Forsburg et al., 2019) for ecological and conservation research. Given the highly variable nature of GC levels across species and study systems (Hau et al., 2016), GCs alone cannot be used as stress indicators and the interpretation of whether a population is stressed certainly requires the input of multivariate factors including repeated measures, evaluation of stress response, recovery, body condition, sex ratio, reproductive rates, time period, field site demographics, and climate (Sapolsky et al., 2000; Dickens and Romero, 2013). Together, these factors provide the basis for improving our understanding of the role of stress in ecological and evolutionary processes on amphibian population declines. Our mini-review explores the following key topics:

1. The role of glucocorticoids in stress physiology and the capacity to cope.

2. Using non-invasive methods vs. plasma or whole-body homogenate in amphibians.

3. Non-invasive sampling of corticosterone profile to the threat of predators in amphibians. a. Fijian ground frogs and the threat of invasive cane toads.

b. Spring-endemic salamanders and the threat of predation by introduced fish.

4. Directions for future research.

\section{THE ROLE OF GLUCOCORTICOIDS IN STRESS PHYSIOLOGY AND THE CAPACITY TO COPE}

Hormone monitoring is part of the toolkit within the emerging field of conservation physiology (Cooke et al., 2013). Monitoring the physiological responses of wildlife to environmental changes by measuring GC stress biomarkers can guide management decisions, thus bolstering both in-situ and ex-situ ecological research and conservation programs (Madliger et al., 2018). In recent years, there have been vast developments in conservation physiology/endocrinology tools, however, further improvements are needed (Madliger et al., 2018). These improvements include a better understanding of the application of stress physiology, creating links between fitness, environmental, and physiological factors, validating techniques across multiple taxa, and establishing tool validation in conservation research programs (Madliger et al., 2018).

GCs help vertebrates respond and recover from challenges (Wingfield et al., 1998; Sapolsky et al., 2000). They may alter investments in growth, survival, and reproduction while mediating life-history trade-offs (Wingfield and Sapolsky, 2003). GC levels and responsiveness can also change through development (Glennemeier and Denver, 2002a) and be sexspecific (Narayan et al., 2012a).

Variation in individual GC levels can indicate the capacity to cope with challenging environments indicating that GCs may be under selection (reviewed by Vitousek et al., 2019b). Variation among individuals within populations also dictates how populations would respond to stress. The ability of individuals in a population to modulate their stress response provides an indication of that population's ability to cope with stressors. In addition to the activation of the GC stress response as part of coping with challenges, it is important that individuals in a population can activate the negative feedback after the perturbation has passed for rapid termination of the stress response (Figure 1). Rapid termination can prevent pathological outcomes of GCs that are elevated over long periods (Romero et al., 2009). In sum, examining the capacity to cope with environmental stressors should include evaluating both the GC stress response and recovery from the perturbation (Vitousek et al., 2019a). To examine these components of the capacity to cope, it is useful to be able to obtain repeated measures from individuals. There is also some evidence that coping capacity varies with components of fitness (reviewed by Vitousek et al., 2019a,b). Thus, the capacity to cope can be examined in relation to fundamental concepts, such as the CORT-Tradeoff, CORT-Fitness, or CORT-Adaptation hypotheses (Breuner et al., 2008; Bonier et al., 2009; Angelier et al., 2010; EscribanoAvila et al., 2013; Guindre-Parker, 2018; Vitousek et al., 2019a), to better understand the functional significance of GCs in 


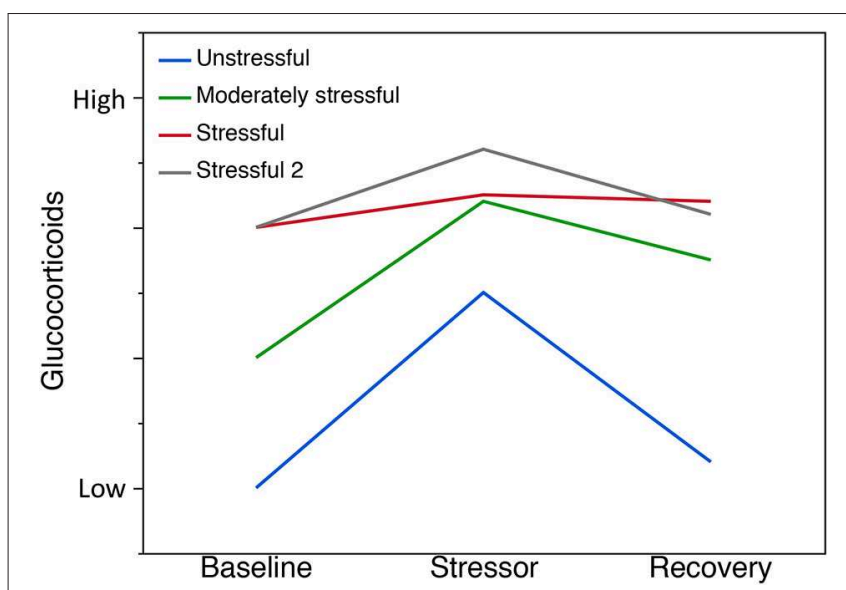

FIGURE 1 | Capacity to cope with environmental stressors. A schematic illustration of putative stress responses. Here, we present scenarios based on the expectation of chronic exposure in benign (unstressful), moderate stress, or severe stress environments. (Note: based on the origin of the study populations, the exact responses may take different forms). The ability to modulate the stress response provides an indication of the ability of a population to cope with stressors. Recovery indicates how quickly individuals in a population can activate negative feedback after the stressor has passed. For example, we propose that populations in unstressful environments will show, on average, low baseline GC, high stress response to an external stressor and high recovery (blue line). In the moderately stressful environment, populations may have higher average baseline GC, show a strong stress response to an external stressor but have a slower recovery (green line). In the stressful environment, populations may have higher average baseline GC, show none or very little stress response to an external stressor and no further change in GCs indicating some level of chronic stress or dysregulation (red line). Alternatively, a population may show the capacity to cope, even when average GCs are high, in the face of a stressful environment (Stressful 2; gray line). Further, GCs could be lower in more stressful environments.

amphibian populations and the responses to environmental change. By evaluating the costs associated with the capacity to cope via the relationship between fitness and CORT across high and low quality environments one may find that different hypotheses are supported in different environments and their associated populations.

\section{USING NON-INVASIVE METHODS vS. PLASMA OR WHOLE-BODY HOMOGENATE IN AMPHIBIANS}

There are a variety of ways to quantify physiological stress responses in animals (Madliger et al., 2018), including measuring GCs from tissues, blood, urine, feces, saliva, eggs, feather, fur, water, and respired air (Madliger et al., 2018). Blood collection from tadpoles and juvenile amphibians is generally challenging, if not infeasible, due to their small body size. Additionally, blood sampling requires sampling within $3 \mathrm{~min}$ of capture to obtain baseline GC levels, which may be difficult in wildlife studies (Romero and Reed, 2005). Further, plasma measures of GC only represent a single time point. Alternatively, GCs can be measured from whole-body homogenate, which may be a more integrated measure, but frequently require pooling multiple individuals to collect enough hormones (reviewed by Burraco et al., 2015). Sampling GCs via whole-body homogenate (and sometimes blood sampling) requires euthanizing individuals, which is often not permitted for threatened or endangered species and counterproductive to conservation efforts. Sequential blood sampling from small species of amphibians may also be difficult; however, minimally invasive techniques are available for amphibian hematology (Heatley and Johnson, 2009).

Traditional blood-sampling and whole-body homogenate methods are still useful in amphibian ecological monitoring. There are several experimental examples of endocrine changes associated with the end-effects of ecologically relevant stressors in amphibians. Studies have shown physiological changes (e.g., changes in plasma corticosterone, immune function, and behavior) associated with exposure to ecologically relevant stressors in amphibians, such as chytrid fungus (Fites et al., 2013), noise pollution (Tennessen et al., 2014), and change in habitat quality (Homan et al., 2003). The foundations for much of this work were built by Glennemeier and Denver (2002a,b,c), who used an adrenocorticotropic hormone (ACTH) challenge to validate the corticosterone response in tadpoles, exposed tadpoles to corticosterone and showed that they uptake corticosterone from the water, blocked corticosterone production with the corticoid synthesis inhibitor metyrapone, and demonstrated the role of corticosterone in mediating the negative effects of increased population density using whole-body homogenates.

Integrated measures of corticosterone profiles using noninvasive methods, such as fecal GC metabolites, water-borne, and urinary GC provide better, and earlier, indicators of chronic stress than do point measures, such as that from blood plasma (Dickens and Romero, 2013). Using GC hormone monitoring, we can obtain valuable information on the role of stress physiology in amphibian (and other organisms) breeding and survival across seasons and years (Boonstra, 2013; de Bruijn and Romero, 2018; Abdelrahman et al., 2019). Further, noninvasive methods of GC collection eliminate the need for euthanizing individuals and represent an integrated measure of episodic changes in cumulative stress over a time period through repeated sampling (Whitten et al., 1998; Touma et al., 2004). Individuals in laboratory, common garden, or exclosuretype studies can be marked and reared in ecologically relevant densities, permitting social interaction, and allowing repeated sampling from the same individual with little or no harm. Noninvasive sampling also allows for reduced sample sizes to estimate temporal patterns and control for individual variation in marked individuals or individually-recognizable individuals in the lab and wild. Hormone metabolites can be quantified through a variety of non-invasive biological samples, such as urine, water, skin swabs, and saliva, and have been used with success to monitor amphibian endocrine functions (Gabor et al., 2013; Narayan, 2013; Hammond et al., 2018; Santymire et al., 2018; Table 1). Measurement of adrenal GC metabolites in urine and feces is of considerable interest to conservation managers as it gives an indication of the link between stress and reproductive success in animals (Carroll et al., 1990; Creel et al., 1997; Wasser et al., 1997; Hopkins et al., 1999; Holt et al., 2003; Pukazhenthi and Wildt, 2004). For example, populations of 
TABLE 1 | Comparison of non-invasive and traditional methods of corticosterone measurement in amphibians.

\begin{tabular}{|c|c|c|c|c|c|c|c|c|}
\hline Method & $\begin{array}{l}\text { Measurement } \\
\text { timeline }\end{array}$ & $\begin{array}{l}\text { Handling and } \\
\text { time to obtain } \\
\text { sample }\end{array}$ & Repeatability & Corrections & $\begin{array}{l}\text { Extraction } \\
\text { methods }\end{array}$ & $\begin{array}{l}\text { Viability in } \\
\text { field }\end{array}$ & $\begin{array}{l}\text { Suitable } \\
\text { species }\end{array}$ & Validation \\
\hline $\begin{array}{l}\text { Water-borne } \\
\text { hormone }\end{array}$ & $\begin{array}{l}\text { Integrated } \\
\text { measure. } \\
\text { Retrospective and } \\
\text { not affected by } \\
\text { initial sampling } \\
\text { procedure }\end{array}$ & $\begin{array}{l}\text { Requires little } \\
\text { handling but } \\
\text { 30-60 min in water }\end{array}$ & $\begin{array}{l}\text { Allows repetitive } \\
\text { sampling without } \\
\text { anesthesia. No time } \\
\text { between sampling } \\
\text { needed }\end{array}$ & None & $\begin{array}{l}\text { Requires single } \\
\text { phase extraction } \\
\text { column }\end{array}$ & $\begin{array}{l}\text { Requires cooler } \\
\text { and ice packs }\end{array}$ & $\begin{array}{l}\text { Mostly smaller } \\
\text { aquatic or } \\
\text { semi-terrestrial } \\
\text { species }\end{array}$ & $\begin{array}{l}\text { Required for } \\
\text { each species but } \\
\text { has consistently } \\
\text { been validated }\end{array}$ \\
\hline $\begin{array}{l}\text { Urinary } \\
\text { glucocorticoid } \\
\text { metabolites }\end{array}$ & $\begin{array}{l}\text { Integrated } \\
\text { measure. } \\
\text { Retrospective and } \\
\text { not affected by } \\
\text { initial sampling } \\
\text { procedure }\end{array}$ & $\begin{array}{l}\text { Requires short } \\
\text { handling to obtain } \\
\text { sample }\end{array}$ & $\begin{array}{l}\text { Allows repetitive } \\
\text { sampling without } \\
\text { anesthesia. May } \\
\text { require time } \\
\text { between sampling }\end{array}$ & $\begin{array}{l}\text { Requires } \\
\text { creatinine } \\
\text { correction }\end{array}$ & None required & $\begin{array}{l}\text { Requires cooler } \\
\text { and ice packs }\end{array}$ & $\begin{array}{l}\text { Mostly larger } \\
\text { terrestrial } \\
\text { species }\end{array}$ & $\begin{array}{l}\text { Required for } \\
\text { each species but } \\
\text { has consistently } \\
\text { been validated }\end{array}$ \\
\hline Buccal swab & $\begin{array}{l}\text { Somewhat } \\
\text { integrated and not } \\
\text { affected by initial } \\
\text { sampling procedure }\end{array}$ & $\begin{array}{l}\text { Requires short } \\
\text { handling to obtain } \\
\text { sample }\end{array}$ & $\begin{array}{l}\text { Allows repetitive } \\
\text { sampling without } \\
\text { anesthesia. May } \\
\text { require time } \\
\text { between sampling }\end{array}$ & None & $\begin{array}{l}\text { Requires TCA } \\
\text { extraction }\end{array}$ & $\begin{array}{l}\text { Requires }-80^{\circ} \mathrm{C} \\
\text { (may be stable } \\
\text { at }-20^{\circ} \mathrm{C} \text { ) }\end{array}$ & $\begin{array}{l}\text { Mostly larger } \\
\text { mostly terrestrial } \\
\text { species }\end{array}$ & $\begin{array}{l}\text { Required for } \\
\text { each new } \\
\text { species }\end{array}$ \\
\hline $\begin{array}{l}\text { Blood } \\
\text { sampling }\end{array}$ & $\begin{array}{l}\text { Immediate } \\
\text { snapshot. Requires } \\
<3 \text { min sampling } \\
\text { time-frame }\end{array}$ & $\begin{array}{l}\text { Requires short } \\
\text { handling to obtain } \\
\text { sample }\end{array}$ & $\begin{array}{l}\text { If animal is large } \\
\text { allows for repeated } \\
\text { sampling with time } \\
\text { between samples. } \\
\text { May require } \\
\text { euthanizing }\end{array}$ & $\begin{array}{l}\text { Requires } \\
\text { measure of CBG } \\
\text { to determine free } \\
\text { or active GCs }\end{array}$ & $\begin{array}{l}\text { Require } \\
\text { centrifuging }\end{array}$ & $\begin{array}{l}\text { Requires } \\
\text { immediate } \\
\text { centrifuge and } \\
-80^{\circ} \mathrm{C}\end{array}$ & $\begin{array}{l}\text { Larger aquatic or } \\
\text { terrestrial } \\
\text { individuals }\end{array}$ & $\begin{array}{l}\text { Does not require } \\
\text { validation }\end{array}$ \\
\hline Whole-body & $\begin{array}{l}\text { Somewhat } \\
\text { integrated but may } \\
\text { be affected by } \\
\text { sampling timeframe } \\
\text { (e.g., <3 min) }\end{array}$ & $\begin{array}{l}\text { Requires little } \\
\text { handling }\end{array}$ & $\begin{array}{l}\text { No repeated } \\
\text { sampling as } \\
\text { euthanizing is } \\
\text { required and may } \\
\text { require pooling data } \\
\text { from multiple } \\
\text { individuals }\end{array}$ & None & $\begin{array}{l}\text { Requires } \\
\text { homogenization } \\
\text { and centrifuging }\end{array}$ & $\begin{array}{l}\text { Requires liquid } \\
\text { nitrogen and } \\
-80^{\circ} \mathrm{C}\end{array}$ & $\begin{array}{l}\text { Smaller } \\
\text { terrestrial or } \\
\text { aquatic } \\
\text { individuals }\end{array}$ & $\begin{array}{l}\text { Requires } \\
\text { validation for } \\
\text { each species }\end{array}$ \\
\hline
\end{tabular}

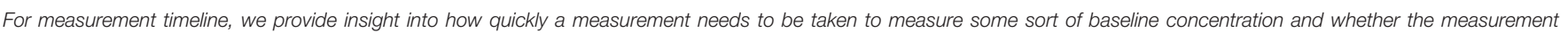

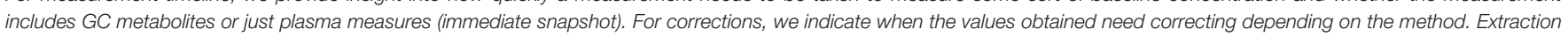

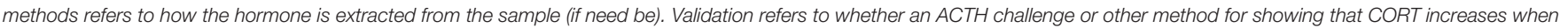
the HPI axis is stimulated is needed.

endangered Jollyville Plateau salamander (Eurycea tonkawae) had elevated water-borne corticosterone release rates in urban streams compared to rural streams in 2 out of 3 years (Gabor et al., 2018a). These results indicate that it is possible to explore environmental and ecological stressors on populations over time using non-invasive measures of GCs, however, it is important that these methods are biologically validated for any new study species.

Non-invasive GC monitoring has been biologically validated for several amphibian species (reviewed by Narayan, 2013; Baugh et al., 2018; Forsburg et al., 2019). Validation involves subjecting the animal to an ACTH challenge and/or an alternative physical stressor (e.g., capture-handling; Narayan et al., 2012a,b) and obtaining the appropriate non-invasive sample (e.g., feces, water, urine, saliva, skin swab) before and after the hormonal stimulation test with the prediction that GCs are elevated after exposure to an exogenous hormone. It is important to quantify the lag-time between the activation of the HPI axis, hormonal response, metabolism, and appearance of the hormonal metabolites of interest in the non-invasively obtained biological sample. Each non-invasive method of GC sampling has inherent benefits and limitations relative to each other and invasive methods (summarized in Table 1). In this table, we do not evaluate the non-invasive dermal swab method because the GCs detected in skin secretions could be independent of the HPI axis as the skin itself is recognized as an endocrine tissue. GC responses in dermal skin secretions are possibly a result of a much slower rate of GC secretion than GC metabolites detected via other non-invasive samples, such as water or urine (Santymire et al., 2018).

\section{Validation of Urinary Corticosterone Profiling}

Urinary GC metabolites (uGMs) are useful indicators of biologically active or plasma-free GCs (reviewed by Narayan, 2013). uGMs require capture and minimal handling ( $<5 \mathrm{~min}$ ), causing slightly elevated metabolite concentrations, however, this allows baseline and short-term stress responses to be assessed over time (Narayan, 2013). Urine sampling devices for anurans are based on the size of each species (e.g., for large anurans, urine can be collected by gentle massage of ventral underbelly area over a sterile cup, blunt pipette 
tips, and micro-capillary tubes; this procedure is described in Narayan, 2013). Anurans are an ideal model for uGMs as they generally urinate frequently, and urine can be preserved at -20 or $-80^{\circ} \mathrm{C}$ (Monfort, 2003). This method has been pharmacologically validated using an ACTH stimulation test in several anurans, including Fijian ground frogs (Platymantis vitiana; Narayan et al., 2010a), Australian Great Barred frogs (Mixophyes fasciolatus; Graham et al., 2013), Stony Creek frogs (Litoria wilcoxii; Kindermann et al., 2012), Bell frogs (Litoria raniformis; Germano et al., 2009), cane toads (Rhinella marina; Narayan and Hero, 2014), and Maud Island frogs (Leiopelma pakeka; Germano et al., 2012). The use of an ACTH stimulation test shows significant changes in uGMs $1-2 \mathrm{~h}$ post-injection. Thus, urine sampling provides a suitable method for assessing the physiological stress responses of anuran amphibians to shortterm environmental challenges, such as transportation (Narayan et al., 2012c), physical marking (Narayan and Gramapurohit, 2019), or exposure to environmental stimulus (e.g., invasive competitor species; Narayan et al., 2013). Measuring GCs via urine is becoming more frequently used over fecal measurements and reduces labor costs (Millspaugh and Washburn, 2004), and uGMs are ideal for amphibian species where fecal samples may not be easy to obtain in the wild. By using uGMs, valuable information can also be obtained regarding the influence of the stress endocrine system on amphibian reproduction (Joshi et al., 2019a). For example, research in both captive and free-living amphibian species have successfully applied uGMs to study the interactions between corticosterone and reproductive hormones, body condition, and breeding behavior (e.g., vocalization in males and vitellogenesis in females; Narayan and Hero, 2013; Joshi et al., 2019b).

\section{Validation of Water-Borne Corticosterone Profiling}

A water-borne method of measuring GCs previously validated for fish (Scott and Ellis, 2007), was recently validated for use with amphibians (Gabor et al., 2013, 2016; Baugh et al., 2018; Forsburg et al., 2019). This method relies on extracting steroid hormones passively diffused into water through the gills, urine, skin, and feces (Scott et al., 2008). The relationship between water-borne corticosterone and plasma corticosterone has been validated in adult and larval common midwife toads (Alytes obstetricans; Gabor et al., 2013), captive-reared and field-collected adult San Marcos salamanders (Eurycea nana; Gabor et al., 2013), and larval Western Tiger Salamanders (Ambystoma mavortium; Davis et al., 2019). All studies found a significant positive correlation between blood plasma and waterborne corticosterone values. Hormones are collected by placing individuals in a standard volume of water (usually $100 \mathrm{~mL}$ ) in an appropriately sized beaker for 30-60 min, and the GC levels are measured as a release rate per hour. Hormones are extracted from water samples using solid phase extraction columns and analyzed using enzyme immuno-assay (EIA) kits (following Gabor et al., 2013, 2016).

In addition to examining the relationship between plasma and water-borne corticosterone values it is also necessary to validate the stress response. Gabor et al. (2016) conducted an ACTH challenge on adult, captive-reared, Eurycea nana. Corticosterone release rates were significantly higher after an ACTH challenge compared to the non-injected control individuals, though corticosterone release rates were not significantly different between the ACTH and saline-injected individuals (likely due to not using high enough concentration of ACTH). Additionally, this method has been pharmacologically validated via ACTH challenges in eastern newts (Notophthalmus viridescens; Reedy et al., 2014) and Rio Grande leopard frogs (Rana berlandieri); Forsburg et al., 2019), and biologically validated using a stressor in E. tonkawae (Gabor et al., 2016), yellow-bellied toad (Bombina variegata), European tree frog (Hyla arborea; Gabor et al., 2017), spotted salamander (Ambystoma maculatum; Charbonnier et al., 2018), Gulf Coast toad (Incilius nebulifer; Gabor et al., 2019), and red-backed salamander (Plethodon cinereus; Novarro et al., 2018). Across all the species examined there is quite a bit of variation in average corticosterone release rates with salamanders showing the lowest values, specifically $P$. cinereus followed by E. nana. Nonetheless, water-borne measures of corticosterone show moderate to high repeatability for $R$. berlandieri when measured every hour for $6 \mathrm{~h}$ repeatedly (Forsburg et al., 2019). Baugh et al. (2018) pharmacologically validated water-borne hormones for Túngara frogs (Physalaemus pustulosus) and demonstrated that water-borne hormone values, measured using EIA, are correlated with those measured using high performance liquid chromatography-mass spectrometry (HPLC-MS). Like urine samples, water-borne extracts can also be used to measure other steroid hormones, such as 17-b estradiol, progesterone, and testosterone in addition to corticosterone from one sample (Narayan et al., 2010b; Mondelli, 2016; Baugh et al., 2018). Further Baugh et al. (2018) validated the use of water-borne extraction to measure 17-b estradiol and progesterone. For water-borne hormones, peak levels of corticosterone release rates require up to $2 \mathrm{~h}$ to be detected ( $P$. pustulosus; Baugh et al., 2018 ) and begin to decline within $2 \mathrm{~h}$ of a stressor (R. berlandieri: Forsburg et al., 2019). Together these results demonstrate that the water-borne hormone method is a useful tool for monitoring populations to measure GCs as an indication of the physiological health of amphibian populations and for exploring the capacity of a population to cope with environmental variation. This non-invasive method is particularly useful for small species of amphibians that are rare or imperiled because it requires less handling. Water samples collected in the field can be stored in a cooler with ice packs until returning to the lab to be stored at $-20^{\circ} \mathrm{C}$, alleviating the need for immediate processing or freezing of blood samples. Further, this method does not require specialized equipment, such as needles and capillary tubes, and facilitates repeated sampling.

\section{NON-INVASIVE SAMPLING OF CORTICOSTERONE PROFILE TO THE THREAT OF PREDATORS IN AMPHIBIANS}

Upon recognition of predators, prey species respond in various ways that generally diminish the direct threat of predation (Lima and Dill, 1990). While these responses generally allow prey 
to survive encounters with predators, there are also nonlethal effects that predators have on prey species. These nonlethal effects are important considerations for the fitness of species, even though they may not be as obvious as direct predation upon individuals. One such nonlethal effect is an elevation in circulating GCs in prey, as found in a wide variety of organisms (Wingfield et al., 1998). Indirect predator interactions, such as competition are associated with nutritional stress and reduced body condition as a result of decreased foraging, triggering an elevation of GC levels (Boonstra et al., 1998; Brown et al., 1999; Creel et al., 2007; Travers et al., 2010; Clinchy et al., 2012; Anson et al., 2013). These circumstances can induce phenotypic dysregulation of an organism, leading to decreased fitness with reduced reproductive success and lower survival (Boonstra et al., 1998; Creel et al., 2007; Travers et al., 2010; Clinchy et al., 2012; Anson et al., 2013). While predators have an important influence on GCs in corticosterone-producing animals (Sapolsky et al., 2000; Romero, 2004), there has been little experimental evaluation of this in free-living amphibians. There are several published studies looking at the topic of amphibian endocrinology when facing predators, with most focused on tadpoles or metamorphs in the laboratory or mesocosms (Hossie et al., 2010; Middlemis Maher et al., 2013; Bennett et al., 2016; Gabor et al., 2019). However, to our knowledge there are no other published studies on predator-prey interactions in rare and endangered amphibian species. Herein we present two case studies that examined stress responses in terrestrial and aquatic amphibian species using non-invasive urine or water-borne GC sampling methods.

\section{Fijian Ground Frogs and the Threat of Invasive Cane Toads}

The island of Viwa within the Fiji Islands is home to the endemic Fijian ground frog (Platymantis vitiana), an IUCN Endangered species. Within this small (60 ha) island, ground frogs are negatively affected by invasive cane toads as they prey on young frogs, but also compete for habitat space and prey. Cane toads were introduced as a bio-control agent (Easteal, 1981), and are now regarded as one of the main threats for Fiji's endemic species (Narayan et al., 2008). Cane toads now persist on multiple Fiji Islands in very high densities and exhibit a strong spatial overlap with ground frogs, suggesting competition for prey and shelter (Thomas et al., 2011). The co-occurrence of ground frogs and cane toads is recent (within this century), making this study system particularly interesting to test the predator-stress hypothesis (Bonier et al., 2009) and to explore the topic of chronic stress in threatened frogs.

Using monthly sampling of urine from captive and free-living ground frogs, Narayan et al. (2010a,b) provided baseline data on the seasonal variation in $\mathrm{uGMs}$ and reproductive hormones in ground frogs. Narayan et al. (2013) demonstrated, using an openfield test set-up, that the presence of cane toads generated uGMs in the ground frogs and also increased tonic immobility (an index of fear response). To better understand the consequences of chronic stress, Narayan et al. (2015) conducted longitudinal trials using outdoor exclosures to study how the presence and absence of cane toads influenced the reproductive ecology of ground frogs. There was a distinct positive correlation between cane toad presence and decreased body condition in both male and female Fijian ground frogs, including sub-clinical changes in stress and reproductive hormones signifying chronic stress (Narayan et al., 2015). Thus, the application of non-invasive hormone monitoring methods in applied field research of an endangered amphibian species has allowed conservation biologists to better understand the consequences of an invasive species and helped guide management.

\section{Spring-Endemic Salamander and the Threat of Predation by Introduced Fish}

Central Texas, USA is home to a diverse group of fully-aquatic salamanders in the genus Eurycea, which inhabit spring and aquifer systems (Devitt et al., 2019). The San Marcos salamander (E. nana), is federally threatened and endemic to the headwaters of the San Marcos River (Nelson, 1993), an area with a diverse assemblage of native and introduced predatory fish. Previous studies have examined the antipredator response of E. nana, demonstrating innate, chemically-mediated predator recognition and that experience modifies these behaviors (Epp and Gabor, 2008; Davis et al., 2012), but little was known about how native and introduced predators influence corticosterone in these salamanders.

While the corticosterone response of prey species exposed to predators may be species-dependent, it may also differ depending on attributes of the predator. High-risk or native predators may elicit a different stress hormone response in prey than low-risk or introduced predators (Lima and Bednekoff, 1999; Chivers et al., 2001). By examining corticosterone levels in the presence of potential predators, a better understanding of how various types of predators (e.g., native, introduced, highrisk, low-risk) influence amphibians can be gained. To better understand the effects of introduced fish predators, Davis and Gabor (2015) exposed E. nana to chemical cues of the native largemouth bass and the introduced redbreast sunfish. Using water-borne hormone collection methods, combined with a repeated measures design, Davis and Gabor (2015) found that the corticosterone response (ratio of the post-stimulus to prestimulus corticosterone release rate) to the native predator was significantly greater than the response to both the introduced predator and blank water control, and that the corticosterone response to the introduced predator was not significantly different than the blank water control. Though previous studies have shown that $E$. nana can recognize redbreast sunfish (Davis et al., 2012), the lower corticosterone response observed by Davis and Gabor (2015) may reflect differences in the temporal variation in the risk between the two predators. The redbreast sunfish is more abundant and likely more frequently encountered compared to the largemouth bass (Perkin and Bonner, 2011) and may account for the muted corticosterone response. Elevated corticosterone release rates are associated with increased energetic expenditure and may aid in quicker escape behavior by salamanders. By incorporating non-invasive stress hormone measures and repeated measures, a more complete 
understanding of how native and introduced predators affect imperiled amphibians and the potential to respond to selection from introduced predators was gained.

\section{DIRECTIONS FOR FUTURE RESEARCH}

With amphibian population declines at the forefront of the global biodiversity extinction crisis, non-invasive methods for quantifying the physiological health of populations is a useful improvement to the field. Measuring hormones via water-borne, urinary GC metabolites, and buccal swab methods in amphibian populations are valuable conservation tools that are minimally invasive and can be completed in the field. Additionally, these methods allow for repeated measurements from the same individuals sequentially or over time. This makes it possible to evaluate the capacity of individuals to cope with environmental changes. By using repeated measures one can determine if individuals in populations are mounting responses to stressors to evaluate if populations are chronically stressed Further, it is essential to look at the rate of recovery from a stressor to explore variation in the capacity to terminate the stress response via negative feedback (Wingfield, 2013; Vitousek et al., 2019a; Zimmer et al., 2019). The faster individuals in a population are able to recover from acute stressors, the likelier the population is able to cope with stressors. When this information is evaluated in relation to fitness, it can provide insights into the costs associated with coping capacity in response to environmental change. Further, assessing whether the "GC phenotype" is a plastic or genetic response to environmental change by using common garden or cross-fostering experiments, whereby individuals can be followed, will aid in our understanding of how selection will act on this phenotype (Ouyang et al., 2019). Together, this information can be used to obtain insights into the overall potential for a population to respond to selection and to explore differences among populations of a given species. Another understudied aspect of stress physiology

\section{REFERENCES}

Abdelrahman, A., Kumstel, S., Zhang, X., Liebig, M., Wendt, E. H. U., Eichberg, J., et al. (2019). A novel multi-parametric analysis of non-invasive methods to assess animal distress during chronic pancreatitis. Sci. Rep. 9:14084. doi: 10.1038/s41598-019-50682-3

Angelier, F., Wingfield, J. C., Weimerskirch, H., and Chastel, O. (2010). Hormonal correlates of individual quality in a long-lived bird: a test of the 'corticosterone-fitness hypothesis'. Biol. Lett. 6, 846-849. doi: 10.1098/rsbl. 2010.0376

Anson, J., Dickman, C., Boonstra, R., and Jessop, T. (2013). Stress triangle: do introduced predators exert indirect costs on native predators and prey. PLoS ONE 8:e60916. doi: 10.1371/journal.pone.0060916

Baugh, A. T., Bastien, B., Still, M. B., and Stowell, N. (2018). Validation of waterborne steroid hormones in a tropical frog (Physalaemus pustulosus). Gen. Com. Endocrinol. 261, 67-80. doi: 10.1016/j.ygcen.2018.01.025

Bennett, A. M., Longhi, J. N., Chin, E. H., Burness, G., Kerr, L. R., and Murray, D. L. (2016). Acute changes in whole body corticosterone in response to perceived predation risk: a mechanism for anti-predator behavior in anurans? Gen. Com. Endocrinol. 229, 62-66. doi: 10.1016/j.ygcen.2016.02.024 in amphibians is how corticosterone, and other hormone profiles, change as an organism develops, which could easily be measured using non-invasive methods (reviewed by Denver, 2009). Research on the relationship between corticosterone, disease, and the skin and gut microbiome across life-stages is also important as it may yield insights into the mechanisms associated with amphibian declines in some populations (e.g., Gabor et al., 2018b). By using non-invasive methods to measure GCs, further insight into the mechanisms associated with amphibian declines can be gained that were once out of reach.

\section{CONCLUSION}

In conclusion, non-invasive hormone monitoring tools can be applied to understand the ecology of amphibians, including rare and endangered species, especially in relation to environmental stressors, such as invasive species, pesticides, disease, and other anthropogenic perturbations. Non-invasive field endocrinology sampling can provide robust data to enable ecologists to make rapid and reliable assessments of the impacts of invasive species on native amphibians and assist with on-ground management and recovery of native species.

\section{AUTHOR CONTRIBUTIONS}

EN and CG synthesized this paper. ZF and DD expanded the discussion.

\section{ACKNOWLEDGMENTS}

We thank Stephanie Deering (University of Western Sydney) for conducting literature search and assisting with earlier drafts. We especially thank I. Gomez-Mestre and two reviewers for their insightful comments that have greatly improved this paper.
Bonier, D., Martin, P. R., Moore, I. T., and Wingfield, J. C. (2009). Do baseline glucocorticoids predict fitness? Trends Ecol. Evol. 24, 634-642. doi: 10.1016/j.tree.2009.04.013

Boonstra, R. (2013). Reality as the leading cause of stress: rethinking the impact of chronic stress in nature. Funct. Ecol. 27, 11-23. doi: 10.1111/1365-2435.12008

Boonstra, R., Hik, D., Singleton, G., and Tinnikov, A. (1998). The impact of predator-induced stress on the snowshoe hare cycle. Ecol. Monogr. 68, 371-394. doi: 10.1890/0012-9615(1998)068[0371:TIOPIS]2.0.CO;2

Breuner, C. W., Patterson, S. H., and Hahn, T. P. (2008). In search of relationships between the acute adrenocortical response and fitness. Gen. Comp. Endocrinol. 157, 288-295. doi: 10.1016/j.ygcen.2008.05.017

Brook, B., Sodhi, N., and Bradshaw, C. (2008). Synergies among extinction drivers under global change. Trends Ecol. Evol. 23, 453-460. doi: 10.1016/j.tree.2008.03.011

Brown, J. S., Laundre, J. W., and Gurung, M. (1999). The ecology of fear: optimal foraging, game theory, and trophic interactions. J. Mammal. 80, 385-399. doi: $10.2307 / 1383287$

Burraco, P., Arribas, R., Kulkarni, S. S., Buchholz, D. R., and Gomez-Mestre, I. (2015). Comparing techniques for measuring corticosterone in tadpoles. Curr. Zool. 61, 835-845. doi: 10.1093/czoolo/61.5.835 
Carroll, J., Abbott, D., George, L., Hindle, J., and Martin, R. (1990). Urine endocrine assessment of the ovarian cycle and pregnancy in Goeldi's monkey (Callimico goeldii). J. Reprod. Fertil. 89, 149-161. doi: 10.1530/jrf.0.0890149

Charbonnier, J., Pearlmutter, J., Vonesh, J., Gabor, C., Forsburg, Z., and Grayson, K. (2018). Cross-life stage effects of aquatic larval density and terrestrial moisture on growth and corticosterone in the spotted salamander. Diversity 10:68. doi: 10.3390/d10030068

Chivers, D. P., Mirza, R. S., Bryer, P. J., and Kiesecker, J. M. (2001). Threat-sensitive predator avoidance by slimy sculpins: understanding the role of visual versus chemical information. Can. J. Zool. 79, 867-873. doi: 10.1139/z01-049

Clinchy, M., Sheriff, M., and Zanette, L. (2012). Predator-induced stress and the ecology of fear. Funct. Ecol. 27, 56-65. doi: 10.1111/1365-2435.12007

Cooke, S. J., Sack, L., Franklin, C. E., Farrell, A. P., Beardall, J., Wikelski, M., et al. (2013). What is conservation physiology? Perspectives on an increasingly integrated and essential science. Cons. Physiol. 1:cot001. doi: 10.1093/conphys/cot001

Creel, S., Christianson, D., Liley, S., and Winnie, J. (2007). Predation risk affects reproductive physiology and demography of Elk. Science 315:960. doi: $10.1126 /$ science. 1135918

Creel, S., Creel, N., and Monfort, S. (1997). Radio-collaring and stress hormones in African wild dogs. Conserv. Biol. 11, 544-548. doi: 10.1046/j.1523-1739.1997.95476.x

Dantzer, B., Fletcher, Q. E., Boonstra, R., and Sheriff, M. J. (2014). Measures of physiological stress: a transparent or opaque window into the status, management and conservation of species? Conserv. Physiol. 2:cou023. doi: 10.1093/conphys/cou023

Davis, D. R., Epp, K. J., and Gabor, C. R. (2012). Predator generalization decreases the effect of introduced predators in the San Marcos salamander, Eurycea nana. Ethology 118, 1191-1197. doi: 10.1111/eth.12025

Davis, D. R., Ferguson, K. J., Schwarz, M. S., and Kerby, J. L. (2019). Effects of agricultural pollutants on stress hormones and viral infection in larval salamanders. Wetlands 1-10. doi: 10.1007/s13157-019-01207-1

Davis, D. R., and Gabor, C. R. (2015). Behavioral and physiological antipredator responses of the San Marcos salamander, Eurycea nana. Physiol. Behav. 139, 145-149. doi: 10.1016/j.physbeh.2014.11.013

de Bruijn, R., and Romero, L. M. (2018). The role of glucocorticoids in the vertebrate response to weather. Gen. Comp. Endocrinol. 269, 11-32. doi: 10.1016/j.ygcen.2018.07.007

Denver, R. J. (2009). Stress hormones mediate environment-genotype interactions during amphibian development. Gen. Comp. Endocrinol. 164, 20-31. doi: 10.1016/j.ygcen.2009.04.016

Devitt, T. J., Wright, A. M., Cannatella, D. C., and Hillis, D. M. (2019). Species delimitation in endangered groundwater salamanders: implications for aquifer management and biodiversity conservation. Proc. Natl. Acad. Sci. U.S.A. 116, 2624-2633. doi: 10.1073/pnas. 1815014116

Dickens, M. J., and Romero, L. M. (2013). A consensus endocrine profile for chronically stressed wild animals does not exist. Gen. Comp. Endocrinol. 191, 177-189. doi: 10.1016/j.ygcen.2013.06.014

Easteal, S. (1981). The history of introductions of Bufo marinus (Amphibia: Anura): a natural experiment in evolution. Biol. J. Linn. Soc. 16, 93-113. doi: 10.1111/j.1095-8312.1981.tb01645.x

Epp, K. J., and Gabor, C. R. (2008). Innate and learned predator recognition mediated by chemical signals in Eurycea nana. Ethology 114, 607-615. doi: 10.1111/j.1439-0310.2008.01494.x

Escribano-Avila, G., Pettorelli, N., Virgós, E., Lara-Romero, C., Lozano, J., Barja, I., et al. (2013). Testing cort-fitness and cort-adaptation hypotheses in a habitat suitability gradient for roe deer. Oecologica 53, 38-48. doi: 10.1016/j.actao.2013.08.003

Fites, J. S., Ramsey, J. P., Holden, W. M., Collier, S. P., Sutherland, D. M., Reinert, L. K., et al. (2013). The invasive chytrid fungus of amphibians paralyzes lymphocyte responses. Science 342, 366-369. doi: 10.1126/science.1243316

Forsburg, Z. R., Goff, C. B., Perkins, H. R., Robicheaux, J. A., Almond, G. F., and Gabor, C. R. (2019). Validation of water-borne cortisol and corticosterone in tadpoles: recovery rate from an acute stressor, repeatability, and evaluating rearing methods. Gen. Comp. Endocrinol. 281, 145-152. doi: 10.1016/j.ygcen.2019.06.007

Gabor, C., Forsburg, Z., Vörös, J., Serrano-Laguna, C., and Bosch, J. (2017). Differences in chytridiomycosis infection costs between two amphibian species from Central Europe. Amphibia-Reptil. 38, 250-256. doi: 10.1163/15685381-00003099

Gabor, C. R., Bosch, J., Fries, J. N., and Davis, D. R. (2013). A non-invasive water-borne hormone assay for amphibians. Amphibia-Reptil. 34, 151-162. doi: 10.1163/15685381-00002877

Gabor, C. R., Davis, D. R., Kim, D. S., Zabierek, K. C., and Bendik, N. F. (2018a). Urbanization is associated with elevated corticosterone in Jollyville Plateau salamanders. Ecol. Indic. 85, 229-235. doi: 10.1016/j.ecolind.2017.10.047

Gabor, C. R., Knutie, S. A., Roznik, E. A., and Rohr, J. R. (2018b). Are the adverse effects of stressors on amphibians mediated by their effects on stress hormones? Oecologia 186, 393-404. doi: 10.1007/s00442-017-4020-3

Gabor, C. R., Perkins, H. R., Heitmann, A. T., Forsburg, Z. R., and Aspbury, A. S. (2019). Roundup ${ }^{\mathrm{TM}}$ with corticosterone functions as an infodisruptor to antipredator response in tadpoles. Front. Ecol. Evol. 7:114. doi: 10.3389/fevo.2019.00114

Gabor, C. R., Zabierek, K. C., Kim, D. S., da Barbiano, L. A., Mondelli, M. J., Bendik, N. F., et al. (2016). A non-invasive water-borne assay of stress hormones in aquatic salamanders. Copeia 104, 172-181. doi: 10.1643/OT-14-207

Germano, J. M., Molinia, F. C., Bishop, P. J., Bell, B. D., and Cree, A. (2012). Urinary hormone metabolites identify sex and imply unexpected winter breeding in an endangered, subterranean-nesting frog. Gen. Com. Endocrinol. 175, 464-472. doi: 10.1016/j.ygcen.2011.12.003

Germano, J. M., Molinia, F. C., Bishop, P. J., and Cree, A. (2009). Urinary hormone analysis assists reproductive monitoring and sex identification of bell frogs (Litoria raniformis). Theriogenology 72, 663-671. doi: 10.1016/j.theriogenology.2009.04.023

Glennemeier, K. A., and Denver, R. J. (2002a). Developmental changes in interrenal responsiveness in anuran amphibians. Int. Comp. Biol. 42, 565-573. doi: $10.1093 / \mathrm{icb} / 42.3 .565$

Glennemeier, K. A., and Denver, R. J. (2002b). Role for corticoids in mediating the response of Rana pipiens tadpoles to intraspecific competition. J. Exp. Zool. 292, 32-40. doi: $10.1002 /$ jez.1140

Glennemeier, K. A., and Denver, R. J. (2002c). Small changes in whole-body corticosterone content affect larval Rana pipiens fitness components. Gen. Com. Endocrinol. 127, 16-25. doi: 10.1016/S0016-6480(02)00015-1

Graham, C., Narayan, E., McCallum, H., and Hero, J. (2013). Non-invasive monitoring of glucocorticoid physiology within highland and lowland populations of native Australian Great Barred Frog (Mixophyes fasciolatus). Gen. Comp. Endocrinol. 191, 24-30. doi: 10.1016/j.ygcen.2013.05.012

Guindre-Parker, S. (2018). The evolutionary endocrinology of circulating glucocorticoids in free-living vertebrates: recent advances and future directions across scales of study. Int. Comp. Biol. 58, 814-825. doi: 10.1093/icb/ icy048

Hammond, T. T., Au, Z. A., Hartman, A. C., and Richards-Zawacki, C. L. (2018). Assay validation and interspecific comparison of salivary glucocorticoids in three amphibian species. Conserv. Physiol. 6:coy055. doi: 10.1093/conphys/coy055

Hau, M., Casagrande, S., Ouyang, J. Q., and Baugh, A. T. (2016). Glucocorticoidmediated phenotypes in vertebrates: multilevel variation and evolution. $A d v$. Study Behav. 48, 41-115. doi: 10.1016/bs.asb.2016.01.002

Heatley, J. J., and Johnson, M. (2009). Clinical technique: amphibian hematology: a practitioner's guide. J. Exot. Pet Med. 18, 14-19. doi: 10.1053/j.jepm.2008.10.004

Holt, W., Pickard, A., Rodger, J., and Wildt, D. (2003). Reproductive Science and Integrated Conservation. Cambridge: Cambridge University Press.

Homan, R. N., Reed, J. M., and Romero, L. M. (2003). Corticosterone concentrations in free-living spotted salamanders (Ambystoma maculatum). Gen. Comp. Endocrinol. 130, 165-171. doi: 10.1016/s0016-6480(02)0 0578-6

Hopkins, W., Mendoca, M., and Congdon, J. (1999). Responsiveness of the hypothalamopituitary-interrenal axis in an amphibian (Bufo terrestris) exposed to coal combustion wastes. Comp. Biochem. Physiol. C 122, 191-196. doi: 10.1016/S0742-8413(98)10104-4

Hossie, T. J., Ferland-Raymond, B., Burness, G., and Murray, D. L. (2010) Morphological and behavioural responses of frog tadpoles to perceived predation risk: a possible role for corticosterone mediation? Ecoscience 17, 100-108. doi: 10.2980/17-1-3312

Idler, D. R. (1972). Steroids in Non-mammalian Vertebrates. New York, NY: Academic Press. 
Joshi, A., Narayan, E., and Grahamapurohit, N. (2019a). Interrelationship among steroid hormones, energetics and vocalisation in the Bombay night frog (Nyctibatrachus humayuni). Gen. Comp. Endocrinol. 246, 142-149. doi: 10.1016/j.ygcen.2016.12.003

Joshi, A. M., Narayan, E. J., and Gramapurohit, N. P. (2019b). Vocalisation and its association with androgens and corticosterone in a night frog (Nyctibatrachus humayuni) with unique breeding behaviour. Ethology 125, 774-784. doi: 10.1111/eth.12931

Kindermann, C., Narayan, E. J., and Hero, J.-M. (2012). Urinary corticosterone metabolites and chytridiomycosis disease prevalence in a free-living population of male Stony Creek frogs (Litoria wilcoxii). Comp. Biochem. Physiol. A 162, 171-176. doi: 10.1016/j.cbpa.2012.02.018

Lima, S. L., and Bednekoff, P. A. (1999). Temporal variation in danger drives antipredator behavior: the predation risk allocation hypothesis. Am. Nat. 153, 649-659. doi: 10.1086/303202

Lima, S. L., and Dill, L. M. (1990). Behavioural decisions made under the risk of predation: a review and prospectus. Can. J. Zool. 68, 619-640. doi: 10.1139/z90-092

Lindsay, W. R., Wapstra, E., Silverin, B., and Olsson,. M. (2016). Corticosterone: a costly mediator of signal honesty in sand lizards. Ecol. Evol. 6, 7451-7461. doi: $10.1002 /$ ece3.2318

Lips, K. R. (2018). Witnessing extinction in real time. PLoS Biol. 16:e2003080. doi: 10.1371/journal.pbio.2003080

Łopucki, R., Klich, D., Scibior, A., Gołebiowska, D., and Perzanowski, K. (2018). Living in habitats affected by wind turbines may result in an increase in corticosterone levels in ground dwelling animals. Ecol. Indic. 84, 165-171. doi: 10.1016/j.ecolind.2017.08.052

MacDougall-Shackleton, S. A., Bonier, F., Romero, L. M., and Moore, I. T. (2019). Glucocorticoids and "stress" are not synonymous. Integr. Org. Biol. 1:obz017. doi: 10.1093/iob/obz017

Madliger, C. L., Love, O. P., Hultine, K. R., and Cooke, S. J. (2018). The conservation physiology toolbox: status and opportunities. Cons. Physiol. 6:coy029. doi: 10.1093/conphys/coy029

McCaffery, R., Solonen, A., and Crone, E. (2012). Frog population viability under present and future climate conditions: a Bayesian state-space approach. J. Anim. Ecol. 81, 978-985. doi: 10.1111/j.1365-2656.2012.01992.x

Middlemis Maher, M. J., Werner, E. E., and Denver, R. J. (2013). Stress hormones mediate predator-induced phenotypic plasticity in amphibian tadpoles. Proc. $R$. Soc. B. Biol. Sci. 280:20123075. doi: 10.1098/rspb.2012.3075

Mills, M., Rader, R. B., and Belk, M. C. (2004). Complex interactions between native and invasive fish: the simultaneous effects of multiple negative interactions. Oecologia 141, 713-721. doi: 10.1007/s00442-004-1695-z

Millspaugh, J., and Washburn, B. (2004). Use of fecal glucocorticoid metabolite measures in conservation biology research: considerations for application and interpretation. Gen. Comp. Endocrinol. 138, 189-199. doi: 10.1016/j.ygcen.2004.07.002

Mondelli, M. J. (2016). Effects of Urbanization on Stress Response of Texas Eurycea salamanders. (Masters Degree). Texas State University. Retrieved from: https:// digital.library.txstate.edu/handle/10877/7748

Monfort, S. (2003). Non-invasive Endocrine Measures of Reproduction and Stress in Wild Populations. Washington, DC: Cambridge University Press.

Narayan, E., Christi, K., and Morley, C. (2008). Ecology and reproduction of the endangered Fijian Ground Frog Platymantis vitianus - Fiji Islands. S. Pacif. J. Nat. Sci. 26, 28-32. doi: 10.1071/SP08004

Narayan, E., Jessop, T., and Hero, J. (2015). Invasive cane toad triggers chronic-physiological stress and decreased reproductive success in an island endemic. Funct. Ecol. 29, 1435-1444. doi: 10.1111/1365-2435. 12446

Narayan, E., Molinia, F., Christi, K., Morley, C., and Cockrem, J. (2010a). Urinary corticosterone metabolite responses to capture, and annual patterns of urinary corticosterone in wild and captive endangered Fijian ground frogs (Platymantis vitiana). Aust. J. Zool. 25, 189-197. doi: 10.1071/ ZO10010

Narayan, E., Molinia, F., Christi, K., Morley, C., and Cockrem, J. (2010b). Annual cycles of urinary reproductive steroid concentrations in wild and captive endangered Fijian ground frogs (Platymantis vitiana). Gen. Comp. Endocrinol. 166, 172-179. doi: 10.1016/j.ygcen.2009.10.003
Narayan, E. J. (2013). Non-invasive reproductive and stress endocrinology in amphibian conservation physiology. Conserv. Physiol. 1:cot011. doi: 10.1093/conphys/cot011

Narayan, E. J., Cockrem, J., and Hero, J. (2012a). Urinary corticosterone metabolite responses to capture and handling in two closely related species of free-living Fijian frogs. Gen. Comp. Endocrinol. 177, 55-61. doi: 10.1016/j.ygcen.2012.02.007

Narayan, E. J., Cockrem, J. F., and Hero, J.-M. (2013). Sight of a predator induces a corticosterone stress response and generates fear in an amphibian. PLoS ONE 8:e73564. doi: 10.1371/journal.pone.0073564

Narayan, E. J., and Gramapurohit, N. (2019). Urinary corticosterone metabolite responses to capture and visual elastomer tagging in the Asian toad (Duttaphrynus melanostictus). Herpetol. J. 29, 179-183. doi: $10.33256 /$ hj29.3.179183

Narayan, E. J., and Hero, J.-M. (2014). Acute thermal stressor increases glucocorticoid response but minimizes testosterone and locomotor performance in the cane road (Rhinella marina). PLoS ONE 9:e92090. doi: 10.1371/journal.pone.0092090

Narayan, E. J., Hero, J.-M., and Cockrem, J. F. (2012b). Inverse urinary corticosterone and testosterone responses to different durations of restraint in the cane toad (Rhinella marina). Gen. Comp. Endocrinol. 179, 345-349. doi: 10.1016/j.ygcen.2012.09.017

Narayan, E. J., and Hero, J. M. (2013). Repeatability of baseline corticosterone and acute stress responses to capture, and patterns of reproductive hormones in vitellogenic and non-vitellogenic female Fijian ground frog (Platymantis vitiana). J. Exp. Zool. A Ecol. Genet. Physiol. 319, 471-481. doi: 10.1002/jez.1810

Narayan, E. J., Molinia, F. C., Cockrem, J. F., and Hero, J.-M. (2012c). Individual variation and repeatability in urinary corticosterone metabolite responses to capture in the cane toad (Rhinella marina). Gen. Comp. Endocrinol. 175, 284-289. doi: 10.1016/j.ygcen.2011.11.023

Nelson, J. M. (1993). Population Size, Distribution, and Life History of Eurycea nana in the San Marcos River. M.S. thesis, Southwest Texas State University, San Marcos, TX.

Novarro, A. J., Gabor, C. R., Goff, C. B., Mezebish, T. D., Thompson, L. M., and Grayson, K. L. (2018). Physiological responses to elevated temperature across the geographic range of a terrestrial salamander. J. Exp. Biol. 221:jeb178236. doi: $10.1242 /$ jeb.178236

Ouyang, J. Q., Baldan, D., Munguia, C., and Davies, S. (2019). Genetic inheritance and environment determine endocrine plasticity to urban living. Proc. R. Soc. B Biol. Sci. 286:20191215. doi: 10.1098/rspb.2019.1215

Perkin, J. S., and Bonner, T. H. (2011). Long-term changes in flow regime and fish assemblage composition in the Guadalupe and San Marcos rivers of Texas. River Res. Appl. 27, 566-579. doi: 10.1002/rra.1373

Pukazhenthi, B., and Wildt, D. (2004). Which reproductive technologies are most relevant to studying, managing and conserving wildlife? Reprod. Fertil. Devel. 16, 33-46. doi: 10.1071/RD03076

Reedy, A. M., Edwards, A., Pendlebury, C., Murdaugh, L., Avery, R., Seidenberg, J., et al. (2014). An acute increase in the stress hormone corticosterone is associated with mating behavior in both male and female red-spotted newts, Notophthalmus viridescens. Gen. Comp. Endocrinol. 208, 57-63. doi: 10.1016/j.ygcen.2014.08.008

Romero, L. M. (2004). Physiological stress in ecology: lessons from biomedical research. Trends Ecol. Evol. 18, 249-255. doi: 10.1016/j.tree.2004.03.008

Romero, L. M., Dickens, M. J., and Cyr, N. E. (2009). The reactive scope modela new model integrating homeostasis, allostasis, and stress. Horm. Behav. 55, 375-389. doi: 10.1016/j.yhbeh.2008.12.009

Romero, L. M., and Reed, J. M. (2005). Collecting baseline corticosterone samples in the field: is under $3 \mathrm{~min}$ good enough? Comp. Biochem. Physiol. A: Molec. Integ. Physiolo. 140, 73-79. doi: 10.1016/j.cbpb.2004.11.004

Santymire, R. M., Manjerovic, M. B., and Sacerdote-Velat, A. (2018). A novel method for the measurement of glucocorticoids in dermal secretions of amphibians. Conserv. Physiol. 6:coy008. doi: 10.1093/conphys/coy008

Sapolsky, R., Romero, L., and Munck, A. (2000). How do glucocorticoids influence stress responses? Integrating permissive, suppressive, stimulatory, and preparative actions. Endocr. Rev. 21, 55-89. doi: 10.1210/er.21.1.55

Scott, A. P., and Ellis, T. (2007). Measurement of fish steroids in water-a review. Gen. Comp. Endocrinol. 153, 392-400. doi: 10.1016/j.ygcen.2006.11.006 
Scott, A. P., Hirschenhauser, K., Bender, N., Oliveira, R., Earley, R. L., Sebire, M., et al. (2008). Non-invasive measurement of steroids in fish-holding water: important considerations when applying the procedure to behavior studies. Behaviour 145, 1307-1328. doi: 10.1163/156853908785765854

Sigwart, J. D., Bennett, K. D., Edie, S. M., Mander, L., Okamura, B., Padian, K., et al. (2018). Measuring biodiversity and extinction-present and past. Integ. Comp. Biol. 58, 1111-1117. doi: 10.1093/icb/icy113

Stuart, S., Chanson, J., Cox, N., Young, B., Rodrigues, A., Fischman, D., et al. (2004). Status and trends of amphibian declines and extinctions worldwide. Science 306, 1783-1786. doi: 10.1126/science.1103538

Tennessen, J. B., Parks, S. E., and Langkilde, T. (2014). Traffic noise causes physiological stress and impairs breeding migration behaviour in frogs. Cons. Physiol 2:cou032. doi: 10.1093/conphys/cou032

Thomas, N., Morrison, C., Winder, L., and Morley, C. (2011). Spatial distribution and habitat preferences of co-occurring vertebrate species: case study of an endangered frog and an introduced toad in Fiji. Conserv. Biol. 17, 68-77. doi: 10.1071/PC110068

Touma, C., Palme, R., and Sachser, N. (2004). Analyzing corticosterone metabolites in fecal samples of mice: a noninvasive technique to monitor stress hormones. Horm. Behav. 45, 10-22. doi: 10.1016/j.yhbeh.2003.07.002

Travers, M., Clinchy, M., Zanette, L., Boonstra, R., and Williams, T. (2010). Indirect predator effects on clutch size and the cost of egg production. Ecol. Lett. 13, 980-988. doi: 10.1111/j.1461-0248.2010.01488.x

Vitousek, M. N., Johnson, M. A., Downs, C. J., Miller, E. T., and Martin, L. B., Francis, C. D., et al. (2019b). Macroevolutionary patterning in glucocorticoids suggests different selective pressures shape baseline and stress-induced levels. Am. Nat. 193, 866-880. doi: 10.1086/703112

Vitousek, M. N., Taff, C. C., Ryan, T. A., and Zimmer, C. (2019a). Stress resilience and the dynamic regulation of glucocorticoids. Integr. Comp. Biol. 59, 251-263. doi: $10.1093 /$ icb/icz087

Wake, D. B., and Vredenburg, V. T. (2008). Are we in the midst of the sixth mass extinction? A view from the world of amphibians. Proc. Natl. Acad. Sci. U.S.A. 105, 11466-11473. doi: 10.1073/pnas.0801921105
Wasser, S., Bevis, K., King, G., and Hanson, E. (1997). Noninvasive physiological measures of disturbance in the northern spotted owl. Conserv. Biol. 11, 1019-1022. doi: 10.1046/j.1523-1739.1997.96240.x

Whitten, P. L., Stavisky, R., Aureli, F., and Russell, E. (1998). Response of fecal cortisol to stress in captive chimpanzees (Pan troglodytes). Am. J. Primatol. 44, 57-69. doi: 10.1002/(SICI)1098-2345(1998)44:1<57::AID-AJP5>3.0.CO;2-W

Wingfield, J., Maney, D., Breuner, C., Jacobs, J., Lynn, S., Ramenofsky, M., et al. (1998). Ecological bases of hormone-behavior interactions: the emergency life-history stage. Integr. Comp. Biol. 38, 191-206. doi: 10.1093/icb/ 38.1.191

Wingfield, J. C. (2013). The comparative biology of environmental stress: behavioural endocrinology and variation in ability to cope with novel, changing environments. Anim. Behav. 85, 1127-1133. doi: 10.1016/j.anbehav.2013.02.018

Wingfield, J. C., and Sapolsky, R. M. (2003). Reproduction and resistance to stress: when and how. J. Neuroendocrinol. 15, 711-724. doi: 10.1046/j.1365-2826.2003.01033.x

Zimmer, C., Taff, C. C., Ardia, D. R., Ryan, T. A., Winkler, D. W., and Vitousek, M. N. (2019). On again, off again: Acute stress response and negative feedback together predict resilience to experimental challenges. Func. Ecol. 33, 619-628. doi: $10.1111 / 1365-2435.13281$

Conflict of Interest: The authors declare that the research was conducted in the absence of any commercial or financial relationships that could be construed as a potential conflict of interest.

Copyright (c) 2019 Narayan, Forsburg, Davis and Gabor. This is an open-access article distributed under the terms of the Creative Commons Attribution License (CC $B Y)$. The use, distribution or reproduction in other forums is permitted, provided the original author(s) and the copyright owner(s) are credited and that the original publication in this journal is cited, in accordance with accepted academic practice. No use, distribution or reproduction is permitted which does not comply with these terms. 